\title{
PLURALISME DALAM PENDIDIKAN ISLAM: STUDI PEMIKIRAN PROF. DR. NURCHOLISH MADJID
}

\author{
Irfan Efendi \\ Universitas Muhammadiyah Malang, Indonesia \\ E-mail: efendiinstitute@gmail.com
}

\begin{abstract}
Abstrak
Pluralisme bukan hanya kesadaran yang bersifat teologis, tetapi juga kesadaran yang bersifat sosial. Hal itu berimplikasi pada kesadaran bahwa manusia hidup di tengah masyarakat yang plural dari segi agama, budaya, etnis dan berbagai keragaman lainya. Pendidikan Islam baik formal maupun non formal, menurut Nurcholish Madjid merupakan jembatan penghubung untuk menginternalisasi nilai-nilai pluralistik atau akidah inklusif kepada peserta didik. Al-Quran merupakan landasan utamapraktik pendidikan Islam. Atas dasar itu, pendidikan Islam dituntut menghadirkan moralitas sosial agar pesan humanistik yang termuat di dalam kitab suci bisa dijadikan pedoman hidup bersosial secara beradab. Riset ini ingin melihat lebih detail tentang kerangka berfikir Nurcholsih Madjid tentang pluralisme agama dalam pendidikan Islam. Penelitian ini menggunakan metode kajian pustaka, sehingga penulisannya merujuk pada sumber tulisan, seperti artikel, jurnal, buku yang sesuai dengan pembahasan riset ini.
\end{abstract}

Kata Kunci: Agama, Kesadaran Teologis, Nurcholish Madjid, Pendidikan Islam, Pluralisme

\begin{abstract}
Pluralism is not only a theological consciousness, but also social consciousness. This has implications for the awareness that humans live in a pluralistic society in terms of religion, culture, ethnicity and various other diversity. According to Nurcholish Madjid, Islamic education, both formal and nonformal, is a bridge to internalize pluralistic values or inclusive creeds to students. Al-Quran is the main foundation of Islamic education practice. On that basis, Islamic education is required to present social morality so that the humanistic messages contained in the holy book can be used as guidelines for civilized social life. This research wants to look in more detail about Nurcholsih Madjid's framework of thinking about religious pluralism in Islamic education. This research uses the literature review method, so that the writing refers to the sources of writing, such as articles, journals, books that are in accordance with the discussion of this research.
\end{abstract}

Keyword: Religion, Theological Consciousness, Nurcholish Madjid, Islamic Education, Pluralism 


\section{Pendahuluan}

Nurcholish Madjid adalah seorang cendekiawan Muslim terkemuka di Indonesia. Ia kerap dipanggil Cak Nur, sapaan akrab yang sangat membumi di kalangan aktivis Muslim. Madjid ditakdirkan muncul sebagai intelektual kelas berat. Fokus pemikirannya berkenaan dengan diskursus keislaman dan kemodernan. Berkat intelektualitasnnya, Madjid dijuluki sebagai Natsir muda. ${ }^{1}$

Menurut Budhy Munawar Rahman, Madjid maupun para penerusnya menyetujui perkataan Dale F. Eickelman seorang ahli Islam kontemporer, "The Qur'an offers a distinctly modern perspective on the role of Islam as a force for tolerance and mutual recognition in a multiethnic, multicommunity world" (Al-Qur'an menawarkan perspektif modern yang jelas tentang peran Islam sebagai kekuatan untuk toleransi dan saling pengakuan dalam dunia multietnis, multi-komunitas). ${ }^{2}$

Menurut pendapat Madjid, ajaran tentang pluralisme agama ini tidak perlu diartikan sebagai kenyataan bahwa paham keagamaan orang-orang Muslim masih banyak yang keliru, karena pada prinsipnya masih bertolak belakang dengan pemahaman dasar Kitab Suci seperti bentuk sikap pemitosan pada sesama makhluk, baik itu yang masih hidup atau yang telah mati.

Kendati paham kemajemukan telah menegaskan pengertian dasar bahwa semua agama telah diberi kebebasan untuk hidup, dengan konsekuensi yang akan ditanggung oleh para penganutnya, baik secara pribadi maupun kelompok, namun sikap tersebut bisa ditafsir sebagai suatu harapan kepada semua keyakinan agama yang ada, yaitu karena semua agama itu pada mulanya menganut prinsip yang sama, yakni tauhid, maka harapan di maksud adalah agar semua golongan agama itu secara perlahan-lahan menemukan kebenaran aslinya sendiri sehingga secara keseluruhan akan kembali kepada satu titik tujuan dan istilah Al-Qur'an-nya disebut kalimah sawa'. ${ }^{3}$

Jadi pluralisme menurut Madjid, adalah sebuah kehendak Tuhan (Sunnatullah) yang tidak akan berubah, sehingga tidak mungkin dapat dilawan atau diingkari keberadaannya. Islam merupakan agama yang sangat tegas mengakui hak agama-agama lain, kecuali yang berdasarkan paganisme atau syirik.

Dewasa ini, pluralisme agama kembali menjadi sebuah perbincangan di dunia pendidikan di Indonesia, terutama dengan kemunculan berbagai tindak kekerasan yang mengatasnamakan agama. Agama dipandang sebagai akar masalah terjadinya konflik

\footnotetext{
${ }^{1}$ Muhammad Wahyuni Nafis, Pengantar Ahmad Syafi'I Ma'arif, Cak Nur Sang Guru Bangsa, Biografi Pemikiran Prof. Dr. Nurcholish Madjid, (Jakarta: Kompas, 2014), hlm. xix.

2 Ahmad Gaus AF, Api Islam Nurcholish Madjid (Jakarta: Kompas, 2010) hlm. 352.

${ }^{3}$ Nurcholish Madjid, Islam Dotrin dan Peradaban...,hlm. 184.
} 
antar umat beragama. ${ }^{4}$

Dengan demikian, perihal dengan peranan pendidikan Islam dan wacana pluralisme agama, dalam hal ini Syamsul Ma'arif berpendapat; “Tujuan pendidikan Islam seharusnya diprioritaskan untuk menumbuhkan saling menghormati kepada semua manusia yang memiliki iman berbeda atau mazhab berbeda, demi mengaktualisasikan tujuan pendidikan Islam tersebut, lembaga pendidikan Islam perlu menerapkan sistem pengajaran yang mengarah pada penananaman kesadaran pluralisme dalam kehidupan. ${ }^{5}$

Dalam pandangan Madjid, pendidikan agama berkisar antara dua dimensi hidup: pertama, penanaman rasa takwa kepada Allah dan kedua, pengembangan rasa kemanusiaan kepada sesama. ${ }^{6}$ Madjid mengemukakan pula bahwa terdapat ikatan yang utuh antara Ketuhanan sebagai dimensi hidup pertama manusia yang vertikal dengan kemanusiaan sebagai dimensi kedua hidup manusia yang horizontal. Oleh karena demikian kuatnya keterkaitan antar dua dimensi itu, maka pendidikan agama, baik di rumah tangga maupun di sekolah tidak dapat disebut "berhasil" kecuali jika pada anak didik tertanam dan tumbuh dengan baik kedua nilai itu: Ketuhanan dan kemanusiaan, takwa dan budi luhur.

Musa Asy'ari menyatakan, proses pendidikan agama yang diterapkan di sekolah ternyata masih bersifat monolog, doktriner, dan formalistis, sehingga yang cenderung menyimpang dari realitas plural keagamaan. ${ }^{7}$ Pemahaman agama dengan pendekatan semacam itu akan melahirkan sikap keagamaan yang ekslusif, truth claim, nihil dialog, tidak utuh, terjebal simbol, mudah mengkafirkan, mengkotak-kotakan umat, tidak ada kerjasama dan tidak terlihat adanya kepekaan sosial.

Maka dari itu pendidikan Islam perlu hadir sebagai solusi atas problem keagamaan, sebagaimana yang sering ditekankan oleh Madjid mengenai pemikiran keagamaannya yang inklusif dan pluralistis, sehingga pendidikan Islam dapat memberikan kontribusi nyata terhadap kerukunan dan perdamaian umat beragama di Indonesia. Ahmad Syafi'i Ma' arif mengungkapkan, adanya perbedaan dari keragaman agama harus bisa kita terima dengan baik dalam satu warna keindonesiaan sehingga bisa menghasilkan sebuah lukisan yang indah. Tentunya dengan formulasi meneguhkan persaudaraan dalam perbedaan dan

${ }^{4}$ Afif Syaiful Mahmudin, Pendidikan Islam \& Kesadaran Pluralisme, Jurnal Ta'limuna, Vol. 7, No.1, 2018, hlm. 9

${ }_{5}^{5}$ Syamsul Ma'arif, The Beuty Of Islam dalam Cinta dan Pendidikan Pluralisme (Semarang: Need's Press, 2008), hlm. 125. Lihat juga dalam Nafik Muthohirin, "Politik Identitas Islam dan Urgensi Pendidikan Multikultural." J-PAI : Jurnal Pendidikan Agama Islam UIN Maulana Malik Ibrahim. Vol. 6. No. 1. JuliDesember (2020)

${ }^{6}$ Nurcholish Madjid, Masyarakat Religius, Membumikan Nilai-Nilai Islam Dalam Kehidupan Masyarakat (Jakarta: Paramadina, 1997), hlm. 96.

${ }^{7}$ Afif Syaiful Mahmudin, Pendidikan Islam E Kesadaran Pluralisme...hlm. 37. 
berbeda dalam bingkai persaudaraan". ${ }^{8}$

\section{Pluralisme Agama Perspektif Nurcholish Madjid}

Latar belakang pemikiran keagamaan Madjid sangat dipengaruhi faktor lingkungan keluarga dan pendidikannya. Untuk memahami pemikirannya sangat diperlukan pendalaman dan pemahaman terhadap pemahamannya tentang Islam. Keberadaannya sebagai tokoh pemikir intelektual Islam berpengaruh di Indonesia saat itu memang cukup banyak mendapatkan aspresiasi dan dukungan sekaligus menuai amarah dikalangan tokoh senior muslim lainnya, sehingga kritik tajam yang di alamatlkan kepada Madjid terbilang cukup keras, bahkan Madjid sendiri pernah merasa terpukul, karena kritikan terhadap gagasan-gagasan yang dikemukakannya, termasuk gagasan tentang pluralisme agama juga datang dari para guru atau tokoh yang disegani oleh Madjid.

Jadi pluralisme agama bagi Madjid, adalah kesimbangan hidup yang terjalin secara harmonis antar sesama pemeluk agama tanpa ada ketegangan yang berujung pada konflik atau kekerasan agama, soal kerukukan umat beragama itu bukan cuma konsep melainkan praksis. Karena Islam merupakan doktrin ajaran yang pakem tentang moralitas kemanusiaan, yang di dalamnya terdapat nilai pluralisme yang kongkret dan tegas sebagaimana penjelasan alQur'an.

Keteranan di atas bisa kita pahami, bahwa Madjid sendiri tidak membenarkan adanya satu agama yang bersifat mutlak, justru terdapat berbagai macam agama yang menuju pada yang Esa. Jika dalam praktiknya terdapat agama yang menyimpang dari konsep Ke-Esa-an, seperti ajaran Kristen Trinitas, maka yang demikian itu tidak bersumber dari ajaran agama yang asli.

Hal tersebut di atas sangat relevan jika pemikiran Madjid tentang keislamannya yang inklusive itu terkontekualisasikan dalam pendidikan Islam. Mengingat fokus Madjid yang dihasilkan pada periode II, pemikiran keislaman-kemodernan tahun 1984-2005 yang berhubungan dengan pemikiran humanisme Islam, yang didalamnya termasuk topik keislaman, sistem demokrasi, HAM dan pluralisme.

Nilai-nilai tersebut menjadi dasar yang cukup otoritatif sebagai landasan kontekstualisasi ajaran Islam Pluralis dalam dunia pendikan Islam. Madjid sendiri telah berhasil menghadirkan beberapa lembaga atau institusi pendidikan sebagai peranti ide dan pemikirannya tentang pluralisme agama.

Bagi Madjid pendidikan agama berkisar kepada dua dimensi hidup: pertama, penaman rasa taqwa kepada Allah dan pengembangan rasa kemanusiaan kepada sesama. ${ }^{9}$ Pendidikan Islam pada intinya berpangkal pada tauhid, tauhid itulah kemudian memancarkan kebaikan dalam tindak tanduknya dalam kehidupan masyatakat yang bernuansa ketuhanan, penuh dengan kedamaian dan sikap kebersamaan terhadap sesama yang berujung pada sikap-sikap

${ }^{8}$ Afif Syaiful Mahmudin, Pendidikan Islam dan Kesadaran Pluralisme, Jurnal Ta'limuna, Vol. 7, No. 1, 2018, hlm. 37-38

'Salito dan Tisna, Pemikiran Pendidikan Islam Nurcholish Madjid, (Pontianak, CV. M-Brother, 2017), hlm. 50. 
pasrah kepada Allah sebagai wujud al-Islam, sikap penuh dengan kedamaian dan kerelaan yang merupakan wujud dari sikap salam dan sikap perubahan kearah perbaikan dalam kehidupan masyarakat dengan wujud islah di dalamnya.

Madjid menerangkan Pluralisme agama sebagai bentuk sikap yang membangun kesadaran teologis dan kesadaran sosial, dalam suasana kehidupan yang heterogen. Lanjut, pluralisme agama wajib dipahami sebagai pertalian yang sejati dalam nafas kebinekaan.

Demikian eratnya hubungan kedua dimensi antara ketuhanan dan kemanusiaan, maka sebab itu pendidikan agama Islam yang dilaksanakan dirumah atau keluarga dan di dalam sekolah formal tidak bisa dikatakan sukses atau berhasil kecuali jika pada peserta didik (anak) telah tertanam dan tumbuh entitas nilai Ketuhanan dan kemanusiaan. ${ }^{10}$

Madjid memberi pernyataan bahwa konsep kemajemukan umat manusia ini sangat mendasar dalam Islam. Itu, secara konsisten, dapat diubah ke dalam bentuk-bentuk pluralisme modern, yang merupakan toleransi. Pluralisme di sini di pahami sebagai ikatan murni dari berbagai peradaban yang berbeda. Pluralisme sejati memang jarang terjadi dalam sejarah, tetapi Islam telah menunjukkan kemungkinan itu.

Melalui teori yang di tulis Dawam Rahardjo dan Madjid sebagaimana di kutip Syamsul Arifin, menyatakan bahwa dalam persoalan agama-agama, pluralisme merujuk kepada sebuah teori atau sikap bahwa semua agama sebenarnya sama, dalam makna bahwa semua agama itu memiliki perspektif masing-masing tentang hakikat jalan menuju kebenaran dan kebijaksanaan Ilahi. Tidak ada satu pun agama yang mengajarkan kesesatan, kejelekan maupun kejahatan.

Madjid menambahkan, "Kerukunan agama perlu dijunjung tinggi, toleransi digencarkan dan saling menghormati antar umat beragama. Sungguh itu bentuk pengalaman dialog, antar keyakinan beragama yang lebih baik, dibandingkan sikap-sikap fanatik, tertutup, radikal dan eksklusif. Mengunci diri dari pergaulan umat agama lain. Pandangan eksklusif itu lawan dari pandangan inklusif dan pluralis. Seorang penganut eksklusifisme tidak akan mau mengakui keyakinan umat agama lain, yang benar baginya adalah keyakinan agama sendiri. ${ }^{11}$

Penjelasan tentang fakta pluralisme atau keberagamaan, Cak Nur melandaskannya pada AlQur'an dan Al-Hadist, di antaranya sebagai berikut ini: Pertama, dan bagi tiap-tiap ummat terdapat petunjuk untuk menghadap kepada-Nya. Maka berlomba-lombalah kamu dalam kebaikan. Dimana saja berada pasti Allah akan mengumpulkan kamu sekalian. Sesungguhnya Allah Maha kuasa atas segala sesuatu (Q.S. 2:148); Kedua, untuk setiap ummat di antara kamu, kami telah berikan ketentuan berupa aturan dan jalan. Seandainya Allah mengendakinya, niscaya kamu bisa dijadikan ummat yang satu. Tetapi ia mengujimu dengan apa yang ia anugerahkan kepada mu. Maka bergiatlah kamu sekalian untuk kebaikan. Kepada Allah lah tempat mu kembali, kemudian ia akan jelaskan kepada mu segala hal yang kamu pernah berseteru di dalamnya itu (Q.S. 5:48); Ketiga, seadannya Tuhan menghendakinya tentu

\footnotetext{
10 Salito dan Tisna, Pemikiran Pendidikan Islam Nurcholish Madjid...hlm. 5

${ }^{11}$ Umi Sumbulah \& Nurjanah, Pluralisme Agama...hlm. 217
} 
akan beriman semua penduduk di bumi, seluruhnya. Maka apakah kamu (Muhammad) akan memaksa manusia lain agar beriman seluruhnya (Q.S. 10:99); Keempat, tidak ada paksaan dalam beragama sesungguhnya jalan hidup yang benar telah jelas berbeda dengan jalan hidup kesesatan (Q.S. 2:256); Kelima, dari Ibn Abbas, ia pernah menuturkan bahwa Nabi SAW ketika ditanya: "agama seperti apa yang paling dicintai oleh Allah? Kemudian "Nabi menjawabnya, "agama dengan semangat kebenaran yang pluralistis hanafiyat alsamhah. ${ }^{12}$

\section{Konteks Pendidikan Islam}

Ada tiga teori untuk menjelaskan sejarah masukkan Islam di Nusantara, yaitu: Teori Gujarat, Teori Mekkah dan Teori Persia. Kemunculan tiga teori ini dalam dugaan Ahmad Mansur Suryanegara, akibat dari kurangnya informasi yang bersumber dari fakta yang jelas tentang peninggalan Islam di Nusantara. Namun peneliti disini tidak akan banyak membahas tentang sejarah persebaran Islam di Indonesia, jadi hanya menjelaskan tentang kondisi sosial keberagamaan masyarakat Indonesia dan corak pemikiran Islam yang berkembang. ${ }^{13}$

Terlepas adanya perdebatan tentang proses pernyebaran Islam di Indonesia beserta akulturasi budayanya. Pada pembahasan ini kita mencoba menelisik corak pemikiran Islam Indonesia. Agus Salim Sitompul dalam tulisannya mencatat, bahwa gerakan Salafiyah telah mengilhami sebagian proses perkembangan sejarah pemikiran Islam di Indonesia, terbukti adanya gerakan Darul Islam di Jawa Barat, pada tahun 1948-1965.

Presiden pertama Bung Karno pernah memberi sebutan GerakanSalafiyah itu dengan sebutan "Purification of Islam Mind and Rejuvenation of Islam Creed". Gerakan Salaf tersebut berpegang tegus terhadap prinsip ajaran Islam, al-Qur'an dan al-Hadist serta menolak bid'ah dan taqlid buta.

Gerakan Salaf menyebar di Indonesia pada tahun 1802 dan berkembang luas di penjuru tanah air, hingga pemikiran mempengaruhi S.M Kartosuwiryo. Pada bulan Maret 1948 bertempat di Majalaya, Jawa Barat, Kartosuwiryo mendirikan Darul Islam, bersama para laskar atau pengikutnya. Lalu pada tanggal 07 Agustus 1949, S.M Kartosuwiryo memproklamasikan Negara Islam Indonesia dan Tentara Islam Indonesia dengan konstitusi sendiri. Namun pada akhirnya Gerakan Salafiyah dan Gerakan Darul Islam tersebut tidak mendapat titik temu, karena DII di cap terlalu politis sedangkan Salafiyah lebih agamis. ${ }^{14}$

Gerakan Islam semacam DII itu tidak lain berangkat dari pengaruh seorang pemikir Islam, Jamal al-Sadabadi atau dikenal dengan julukan al-Afgani, dia lah sosok yang pernah menggagas konsep negara Islam. Pada awal mulanya, gerakan itu di sebut dengan modernisme Islam, selain politis dan mereka juga menyerukan semangat perlawanan terhadap hegemoni Barat. Jika dinilai dari semangatnya, gerakan semacam itu ada sisi positifnya

\footnotetext{
12 Syamsul Arifin, Konstruksi Wacana Pluralisme Agama di Indonesia... hlm. 89-90

${ }^{13}$ Khozin, Jejak-Jejak Pendidikan Islam di Indonesia, (Malang, UMM Press, 2006). hlm. 34.

${ }_{14}$ Drs. Agus Salim Sitompul, HMI Dalam Pandangan Seorang Pendeta (Jakarta, Gunung Agung, 1982).
} 
meskipun tampak bercorak fundamentalistik. ${ }^{15}$

Fazlur Rahman menilai, meskipun pendiri gerakan modernis Islam itu Al-Afgani, dia sendiri tidak menampakkan karakter modernisme intelektual. Melalui Pan-Islamisme ia melancarkan program politiknya, dengan tujuan untuk menentang penetrasi Eropa pada abad $19 \mathrm{M}$ dan Al-Afgani sendiri juga memegang pahamWahabi.

Pengalaman tersebut lalu berdampak bagi watak masyarakat muslim di Indonesia. Kebencian umat yang berlebihan terhadap para penjajah sangat berdampak negarif bagi perkembangan pendidikan Islam di Indonesia. Pada akhir abad ke 19, kaum ulama dan para santrinya memusatkan pendidikan tradisionalnya di berbagai pesantren sambil menutup diri dari sesuatu yang berbau asing. ${ }^{16}$

Pengalaman kolonial cukup berpengaruh secara signifikan terhadap penguatan kelompok konservatif Islam, bukan hanya di Indonesia saja melainkan seluruh dunia Islam. Perkembangan konservatisme Islam muncul di berbagai pesantren pada permulaan abad ke 20. Gerakan Islam terbesar dengan latar pesantren adalah Nahdlatul Ulama (NU) berdiri pada tahun 1926 di Surabaya. Selain NU, masih terdapat lagi gerakan konservatif lokal, seperti Nahlatul Wathan (NW) di Lombok, Perti (Persatuan Tarbiyah Islamiyah), AlWashliyah dan PUI (Persatuan Umat Islam) di Jawa Barat. ${ }^{17}$

Sikap konservatif hampir menjangkit pesantren NU, selain itu pesantren memiliki ciri atau sikap mencurigai terhadap pihal luar. Gus Dur memandang sikap ini mengandung dua konsekuensi logis, yaitu sikap tertutup pesantren dan berkembangnya tingkat solidaritas yang tinggi di berbagai pesantren, terutama pesantren di bawah pengaruh kyai tradisional. ${ }^{18}$

Sikap curiga ini dipengaruhi pengalaman kelam para ulama dan para tentara kolonial di masa lampau. Boleh jadi juga sebagian besar pesantren di Indonesia belum mengenalkan pandangan dan penafsiran modern Islam kepada para santri. Misalnya Al-Manar Rasyid Ridha yang banyak memuat pemikiran Abduh belum terlalu banyak dikenalkan di pesantren. Dalam konteks ini Saifuddin Zuhri berpendapat, bahwa Islam mustahil untuk di modernkan, jika itu terjadi, maka itu bukan Islam. Saifuddin Zuhri menganggap bahwa modernisme Islam itu kata lain dari Islam yang di sekulerkan. Soal perkara ini mungkin sudah banyak yang membahasnya. ${ }^{19}$

Pengaruh pengajaran sufisme (tarekat) terbilang sangat kuat di kalangan pesantren tertentu, maka tidak keliru jika Deliar Noer memberi istilah figh oriented sangat mendominasi

\footnotetext{
15 Pengantar Moeslim Abdurrahman, Sebuah Gagasan Keagamaan dalam Sejarah Politik (Jakarta, LP3ES, 2006). hlm. xii

${ }^{16}$ Ahmad Syafi'i Ma'arif, Islam dan Pancasila Sebagai Dasar Negara (Jakarta, LP3ES, 2006). Hlm. 56

17 Ahmad Syafi'i Ma'arif, Islam dan Pancasila...hlm. 57

18 Ahmad Syafi'i Ma'arif, Islam dan Pancasila...hlm. 60

${ }^{19}$ Ahmad Syafi'i Ma'arif, Islam dan Pancasila...hlm. 61
} 
pendidikan dan pengajaran Islam di Indonesia, terutama pesantren.

Kemudian kita akan membahas soal isu ini dalam kaca mata modernis Islam. Jika kita menganalisis sistem pendidikan tradisional seperti pesantren yang sudah dibahas sebelumnya, kita melihat masih terdapat kelemahan atau kekurangan dalam dunia pendidikan Islam kita. Al-Qur'an tidak diajarkan secara komprehensif melalui metodologi pengajaran yang kritis untuk memahami Islam secara utuh. Jadi mustahil jika hal semacam ini masih tetap ada, tidak mungkin bagi kita mengharapkan pengajaran model itu akan mampu membawa perkembangan sikap mental muslim yang kreatif, konstruktif dan tanggung jawab terhadap problem kemanusiaan..$^{20}$

Lantas seperti apakah tujuan pendidikan Islam dalam pandangan seorang modernis Islam, Fazlur Rahman yang sekaligus guru Madjid. Menurut Rahman, tujuan pendidikan menurut pandangan al-Qur'an adalah untuk mengembangkan kemampuan mental dan intelektual inner faculties manusia, sehingga seluruh pengetahuannya menyatu secara organik dengan kepribadiannya secara kreatif. Rahman membangun narasinya berdasar pada ayat alQur'an: "Kami telah mendelegasikan kepadamu seorang Rasul dari kalangan kamu sendiri, yang membacakan ayat-ayat kami dan menjadikan kamu tumbuh dan mengajarkan kepadamu kitab kebijaksanaan dan mengajarkan apa yang belum diketahui mu. (11:151).

Lalu bagaimana posisi kaum modernisme Islam di Indonesia dan kaitannya dengan gagasan Islam sebagai kekuatan moral pembebas. Terhitung sejak awal abad ke 20, di Indonesia telah tersebar luas paham modernisme Islam, mereka tergolongan gerakan modernisme Islam, seperti Sarekat Islam, Masyumi, Muhammadiyah, Persis (Persatuan Islam) dan Al-Irsyad sedangkan di tingkat mahasiswa Islam dan pelajar Islam diwakilkan kepada Himpunan Mahasiswa Islam (HMI) dan Pelajar Islam Indonesia (PII). Dari beberapa organisasi Islam tersebut ide-ide tentang modernisme Islam dipromosikan melalui agenda-agenda sosial, ekonomi dan pendidikan. ${ }^{21}$

Dari deskripsi di atas, perlu kiranya kita melakukan ikhtiar intelektual untuk menyelesaikan problem-problem yang sedang kita hadapi dalam dunia Islam dewasa ini, dengan melakukan refeleksi kritis melalui substansi pemikiran Nurcholish Madjid tentang narasi agama dan kemanusian lebih tepatnya tentang pluralisme agama dalam konteks pendidikan Islam.

Pada periode ke II pemikiran Madjid ini telah menjadi sinyal pengingat bagi masyarakat muslim di Indonesia. Pada tahun 1973-1984, pasca kepulangannya dari kuliah di Chicago, Madjid kembali mengaktualkan kembali gagasan pembaharuannya pada tahun 1970 . Tulisan Madjid yang pertama kemudian terbit saat sebelum pulang dari Chicago, dalam bukunya yang berjudul "Cita-cita Politik Kita".

Persoalan tentang hubungan antara agama dan negara, Rasulullah SAW telah memberikan contoh yang baik. Madjid menjulukinya dengan istilah (ekspreimen Madinah) untuk

\footnotetext{
${ }^{20}$ Ahmad Syafi'i Ma'arif, Islam dan Pancasila...hlm. 62

${ }^{21}$ Ahmad Syafi'i Ma'arif, Islam dan Pancasila...hlm. 63-64
} 
menegakkan sebuah civil society yang memiliki karakteristik egalitarianisme. ${ }^{22}$

Madjid memberi penjelasan, dalam eksperimen Madinah ini, Rasul telah mencontohkan kepada segenap manusia sebuah tata kelola sosial politik, lalu ekperimen Madinah tersebut dikenal dikenal sebagai Piagam Madinah (Mistsaq al- Madinah). Para sarjana politik Islam dikenal dengan istilah (Konstitusi Madinah).

Istilah pemikir Islam kontemporer menyebutnya dengan nilai egalitarianisme, demokrasi, partisipasi dan keadilan sosial, merupakan sebuah tantangan tersendiri dalam pemikiran sosial-politik Islam dewasa ini, termasuk di dalamnya pluralisme.

Madjid sendiri mendalami makna modern kehidupan masyarakat Madinah pada masa Nabi Muhammad, sebagai bentuk strategi mempermudah umat Islam Indonesia menerima secara utuh sistem Pancasila. Mengingat perdebatan Islam dan Pancasila masih kerap terjadi dan ini tidak bisa dibiarkan terus menerus, karena Pancasila dan Islam sendiri tidak bisa di perdebatkan karena hal tersebut telah final seperti halnya Piagam Madinah yang di konsepsikan nabi dan rakyatnya.

Lalu bagaimanakah formulasi pendidikan Islam yang semestinya dibangun berdasarkan landasan keislaman yang sejalan dengan prinsip kemanusiaan universal sebagaimana yang banyak dipaparkan Madjid dalam setiap karyanya yang monumental. Apakah pendidikan Islam di masa yang akan datang mampu menjawab semua problem sosial dan keagamaan di hari depan dan seperti apa yang tawaran pendidikan Islam ditengah-tengah masyarakat yang majemuk (plural) ini.

Ali Maksum menyatakan, kegagalan agama dalam memainkan peranannya sebagai juru damai problem solver bagi persoalan SARA erat kaitannya dengan pengajaran agama secara eksklusif alias tertutup. Maka dari itu, sudah saatnya pendidikan Islam itu mengedepankan nilai inklusif, humanis dan multikultural. ${ }^{23}$

Maksum menambahkan, pada tataran teologis, pendidikan agama perlu mengubah paradigm teologis yang pasif, tektualis dan eksklusif menuju teologi yang inklusif, saling menghormati, saling mengakui eksistensi dan bersikap positif. Dalam konteks ini, muaranya adalah untuk membangun interkasi antar umat beragama yang tidak hanya berkoeksistensi secara harmonis dan damai, tetapi juga bersedia aktif dan pro-aktif dalam wilayah kemanusiaan.

Saat menyampaikan ceramah budaya di Taman Ismail Marzuki pada 21 Oktober 1992, Madjid telah menampilkan gagasannya dengan mengusulkan model pemahaman dan pengamalan kehidupan keagamaan melalui wacana posmodernisme. Ia telah menawarkan suatu konstruksi teologis yang dipandang relevan dalam menghadapi kehidupan pascamodern. Kendati hal ini secara eksplisit tidak ia nyatakan langsung, namun jika

\footnotetext{
22 Budhy Munawar Rahman, Kata Pengantar Karya Lengkap Nurcholish Madjid...hlm. lxvi-lxvii

${ }^{23}$ Ali Maksum, Pluralisme dan Multikulturalisme Paradigma Baru Pendidikan Agama Islam di Indonesia, (Yogyakarta: Aditya Media Publishing, 2011)
} 
menelisik pemikirannya, kita dapat memasuki dimensi ke arah itu. Hal ini bisa dilihat dari beberapa gagasan pemikirannya, seperti: pluralisme, toleransi, deabsolutisme kebenaran suatu penafsiran teks dan dekonstruksi pemahaman keagamaan. Berkenaan dengan itu, barangkali yang menarik untuk dipertanyakan adalah mengapa dalam sebuah ceramah budaya itu, Madjid banyak berbicara tentang teologi, soal pemahaman agama. ${ }^{24}$

"Al-Qur'an itu sebenarnya lebih banyak mengajarkan etika, memang ada perintah sholat misalnya. Tapi itu sebenarnya "pakunya" dan "mozaiknya" itulah yang membuatnya indah. Itu sebenarnya yang mau saya katakan dalam makalah saya di TIM." Demikianlah salah satu kutipan pernyataan Madjid yang sedikit banyak memberikan penegasan mengapa wacana keagamaan ia usung dalam sebuah ceramah budayanya. Pengusungan tersebut dilakukan dengan maksud untuk menjadikan etika Islam, nilai-nilai Islam, sebagai bagian integral paradigma berbangsa dan bernegara. Madjid ingin agar nilai-nilai Islam yang luhur itu dapat teraktualisasikan dalam kehidupan masyarakat Indonesia yang notabenenya mayoritas beragama Islam (muslim).

Dalam konteks ini, Madjid sebenarnya telah menawarkan sebuah paradigma etis yang diusungnya dari al-Qur'an. Ia telah menyodorkan paradigma etika teologis itu menghentak pusat kesadaran manusia. Dialektika teologis, hakikatnya akan selalu berkaitan dengan aktivitas mental berupa kesadaran manusia yang paling dalam tentang relasi manusia dengan Allah dan lingkungan sosialnya, yang kemudian terwujud dalam moralitas kemanusiaannya.

Sebagai agama yang memiliki watak kosmopolit dan universal, manifestasi etika Islam dalam konteks keindonesiaan dan kemoderan mempunyai spesifikasi yang sangat tinggi. Menjadikan nilai-nilai keislaman "down to earth" atau "membumi" adalah sebuah keniscayaan terlebih lagi dengan karakteristik masyarakat yang bineka. Oleh karena itu, sangat tepat bagi Madjid menawarkan konsep-konsep teologi pluralisme yang digali dari yaiAl-Qur'an. Menurutnya, pluralisme inilah salah satu ajaran pokok Islam yang amat relevan dengan zaman sekarang.

Pendidikan sebagaimana dikatakan oleh para ahli, tidak hanya berperan sebagai media strategis untuk mengajarkan ilmu (transfer of knowledge), tetapi pendidikan peranan yang lebih luhur sebagai media strategis untuk merealisasikan nilai-nilai (transfer of values). Tanpa merealisasikan teologi pluralisme dalam dunia pendidikan, kiranya akan sulit melakukan upaya untuk membumikan etika pluralisme sebagai landasan etis bagi kehidupan masyarakat.

Teologi pluralisme yang diajarkan di pendidikan Islam diharapkan akan mampu mengkonstruksi kesadaran manusia untuk berkiprah seiring dengan realitas zaman. Membangun kesadaran bahwa manusia diciptakan sama sehingga tidak dibenarkan

${ }^{24}$ Muhammad ln'am Esha , Teologi Pluralisme Dalam Pendidikan Islam Mencermati Implikasi Pemikiran Nurcholish Madjid, Jurnal Ulul Albab; Vol. 5 No. 2, 2004. hlm. 128-129. 
munculnya segala diskriminasi manusia satu atas lainnya karena perbedaan agaam; membentuk kesadaran bahwa manusia pada hakikatnya mempunyai tujuan yang sama dalam beragama yaitu mencapai the ultimate concern, sehingga tidaklah dibenarkan saling menafikan antara pemeluk satu agama terhadap agama-agama lain. Penanaman kesadaran semacam ini dapat dimulai dengan pengajaran teologi pluralisme dalam pendidikan Islam. ${ }^{25}$

Hal ini adalah menjadi keniscayaan karena, sebagaimana dijelaskan Amin Abdullah, isu-isu kemanusiaan yang muncul dewasa ini tidak dapat diatasi lewat pemahaman akidah dalam format ilmu kalam klasik yang lebih menekankan kesalamatan individual, bukan keselamatan sosial. Perkembanga sosial-kemasyarkatan kontemporer, yang dihadapi manusia amatlah berbeda dengan yang dirasakan oleh umat manusia terdahulu. Sehingga perbincangan tauhid sosial perlu dilakukan agar tidak terjadi intellectual gap dan historical gap antara keberagamaan Islam seperti yang di cita-citakan dalam realitas masyarakat muslim, menjadi sebuah keniscayaan.

Inkluditas pemikiran teologi pluralisme yang dikonstruksi Madjid dalam pendidikan Islam kontemporer, dengan demikian menemukan momentumnya dalam upaya mewujudkan dan menjadikan agama, meminjam istilahnya Djamannuri, sebagai major social force, sebagai landasan etika dalam kehidupan masyarakat modern di mana pluralisme adalah keniscayaan yang tidak bisa ditentang. Teologi pluralisme yang digali dari konsep-konsep universalisme Islam diharapkan dapat mendorong terciptanya "genuine engament of diversities whithin the bonds of civility" (pertalian sejati kebhinekaan dalam ikatan-ikatan keadaban). ${ }^{26}$

Pluralisme secara teologis, berarti bahwa manusia harus menangani perbedaan-perbedaan manusia dengan cara terbaik "fastabiqu al-khairat" atau berlomba-lomba dalam kebaikan, istilah al-Qur'an ini diperkenalkan Madjid, secara maksimal, sambil menaruh penilaian akhir mengenai kebenaran kepada Tuhan. Karena tidak ada satu cara pun yang bisa dipergunakan secara obyektif untuk mencapai kesepakatan mengenai kebenatan mutlak ini. ${ }^{27}$

Perihal dengan landasan etis pendidikan Islam, Madjid pernah mengatakan; “Jadi, jelas bahwa pendidikan agama tidak dapat dipahami secara terbatas hanya pengajaran agama. Karena itu keberhasilan pendidikan agama bagi anak-anak tidak cukup diukur hanya dari seberap jauh anak itu menguasai hal-hal yang bersifat kognitif atau pengetahuan tentang ajaran agama atau ritus-ritus keagamaan semata. Justru yang lebih penting, berdasarkan ajaran kitab dan sunnah sendiri, ialah seberapa jauh tertanam nilai-nilai keagamaan tersebut dalam jiwa anak, dan seberapa jauh pula nilai-nilai itu mewujudkan nyata dalam tingkah laku dan budi pekertinya, sehari-hari. Dan perwujudkan nyata nilai-nilai tersebut dalam tingkah

\footnotetext{
${ }^{25}$ Muhammad ln'am Esha , Teologi Pluralisme Dalam Pendidikan Islam...hlm. 130-131.

${ }^{26}$ Muhammad ln'am Esha , Teologi Pluralisme Dalam Pendidikan Islam...hlm. 132.

${ }^{27}$ Ahmad Gaus AF, Api Islam Nurcholish Madjid...hlm. 353.
} 
laku dan budi pekerti sehari-hari akan melahirkan budi luhur" ${ }^{28}$

Dari penjelasan tersebut, Madjid juga menyatakan bahwa terdapat keterkaitan yang mutlak antara dimensi vertikal manusia dengan Tuhan dan dimensi horizontal manusia dan kemanusiaan. Dan nilai-nilai akhlak yang patut ditanamkan dalam ranah dimensi yang kedua ini yaitu kemanusiaan meliputi silaturrahmi, persaudaraan, adil rendah hati, tepat janji, lapang dada, perwira, hemat dan dermawan. ${ }^{29}$ Penekanan pada wilayah pendidikan akhlak dalam kehidupan, Madjid juga menjelaskan perihal akhlak dan tasawuf: "Pengajaran tasawuf hendaknya menanamkan ke dalam jiwa anak didik kesadaran akan hadirnya Tuhan dalam hidup dan Tuhan selalu mengawasi segala tingkah laku manusia. Dari segi ini tampak jelas betapa eratnya rasa Ketuhanan, takwa, ihsan, atau religiusitas dengan rasa kemanusiaan (insaniyah), amal saleh, akhlak, budi pekerti atau tingkah laku etis. ${ }^{30}$

Beberapa penjelasan Madjid diatas, jika saja dipertanyakan mengenai segala pemikirannya, apakah Madjid hanya seorang tokoh yang hanya mampu memainkan peranananya pada tataran konsep dan gagasan saja atau ia memiliki andil yang jauh lebih besar. Alangkah baiknya jika mendefiniskan Madjid dalam hal ini, kiranya perlu meminjam istilah Gramsci tentang istilah intelektual organik. Intelektual organic adalah deskripsi seorang figur atau kelompok intelektual yang mendidikasikan dirinya untuk perjuangan menuju kebaikan kelompok sosial masyarakatnya. ${ }^{31}$

Dalam konsep intelektual, Gramsci menyatakan: "All men are intellectuals, but not all men have in society the function of intellectuals". Menurutnya, banyak orang yang bisa menjadi intelektual, tetapi tidak semuanya di masyarakat itu yang bisa memainkan fungsi sebagai intelektual. ${ }^{32}$

Kemunculan intelellectual organic pada kolektivitas muslim modern ada lah dari para komunitas intelegensia dan clerical intelligentsia (intelektual klerikus), Yudi Latif menyebutnya sebagai ulama intelek, yang memiliki kualifikasi pendidikan yang sebagai sumber legitimasi intelektualnya.

Senada dengan Muslim Abdurrahman, meminjam istilahnya Bauman dan Keller, Muslim menjelaskan tentang "subaltern intellectual" adalah gagasan sosial baru, yakni mereka berperan sebagai articulator dalam arti berperan selalu critical oppositional intellectual terhadap tatanan yang mapan dalam ketidakadilan. Karakter intelektual kekaryaan (fungsional) yang berperan di ranah publik adalah mereka yang membela kepentingan publik. Ia selalu peka dan mampu memberi narasi serta menulis tentang ketidakadilan

\footnotetext{
28 Ahmad Gaus AF, Api Islam Nurcholish Madjid...hlm. 354

${ }^{29}$ Salito dan Tisna, Pemikiran Pendidikan Islam Nurcholish Madjid...hlm. 106

${ }^{30}$ Salito dan Tisna, Pemikiran Pendidikan Islam Nurcholish Madjid...hlm. 107

${ }^{31}$ Agus Afandi, Gerakan Sosial Intelektual Muslim Organik dalam Transformasi Sosial, Religio: Jurnal Studi Agama-Agama, Vol. 1, No, 2, 2011. hlm. 98.

${ }^{32}$ Agus Afandi, Gerakan Sosial Intelektual Muslim Organik... hlm. 98.
} 
dalam lingkup publik, mengutarakan ketertindasan, sekaligus menjadi saksi dan dengan episteme intelektual, serta mengadakan kritik terhadap dosa-dosa sosial demi pembelaan terhadap nilai-nilai kemanusiaan. ${ }^{33}$

Menyambut dari penjelasan di atas, dalam hal ini Madjid bukan seorang intelektual yang hanya berdiri di menara gading dalam mengartikulasi gagasan pemikirannya, ia justru turut serta atau terlibat aktif untuk mengeksekusinya di lapangan. Adapun beberapa institusi yang pernah menjadi tempat bagi Madjid untuk menyebar luaskan ide dan pemikirannya melalui sebuah pelembagaan pemikirannya, antara lain: Himpunan Mahasiswa Islam (HMI), Ikatan Cendekiawan Muslim (ICMI), Yayasan Wakaf Paramadina atau Universitas Paramadina, Sekolah Sevila, Sekolah Madania, Yayasan Membangun Kembali Indonesia (PMKI).

\section{Penutup}

Hasil penelitian ini menyimpulkan sebagai berikut: Pertama, Konsep Pluralisme Nurcholish Madjid didasarkan pada al-Qur'an dan Hadist, Madjid menegaskan bahwa pluralisme agama merupakan sebuah kenyataan (sunnatullah), yang telah menjadi kehendak Allah SWT. Landasan pluralisme agamanya juga didasarkan pada konsep civil society "masyarakat Madani" yang dimuat dalam "Piagam Madinah" oleh Nabi Muhammad SAW, sehingga jelas bahwa pluralisme agama Nurcholish Madjid memiliki dasar otoritatif yang mengakar secara teologis dan sosio-historis kerasulan Muhammad yang berhasil membangun kehidupan sosial-politik yang menjunjung tinggi nilai-nilai: egalitarianisme, demokrasi, partisipasi dan keadilan sosial.

Kedua, pendidikan Islam menurut Nurcholish Madjid setidaknya dijadikan sebagai sarana pembentukan akhlak dan kepribadian yang didasarkan pada moralitas kemanusiaan sebagaimana yang terkandung dalam prinsip ajaran Islam. Nilai ketakwaan dan kemanusiaan menjadi core dalam pelaksanaan pendidikan Islam di Indonesia.

Ketiga, pemikiran pluralisme agama Nurcholish Madjid dalam konteks pendidikan Islam, teraktualisasi di dalam pelembagaannya melalui pendidikan formal, adapun indikasinya adalah, Nurcholish Madjid berhasil mendirikan Universitas Paramadina. Paramadina dirancang sebagai pusat kegiataan agama dan pendidikan yang memadukan antara tradisi dan modernitas. Dalam rumusan tujuan pendirian Paramadina, Nurcholish Madjid merumuskan: Pertama, keterbukaan dalam pandangan dan tanggung jawab diri sebagai khalifah. Kedua, Keilmuan, Kemerdekaan dan Penghambaan Ilahi. Ketiga, Tradisi ilmiah yan kritis melalui yang dialog kritis, bernalar dan bertanggung jawab. Keempat, Sistem pendidikan agama yang maju berkualitas dan kompetitif.

Konsep pluralisme agama Nurcholish Madjid yang dibangun atas landasan teologis dan sosio-historis merupakan formulasi yang sangat relevan untuk dijadikan prinsip pendidikan Islam di Indonesia. Nurcholish Madjid merupakan seorang santri dan tokoh intelektual muslim yang memberi perhatian lebih terhadap pendidikan pluralisme agama di Indonesia. Kehadirannya di tengah-tengah kita, sangat berdampak baik bagi konstruksi kesadaran masyarakat muslim dalam memahami prinsip-prinsip keislaman dan keindonesiaan. Cak

${ }^{33}$ Agus Afandi, Gerakan Sosial Intelektual Muslim Organik...hlm. 100 
Nur menilai dua entitas itu saling berkaitan, integrasi nilai islam dan kebangsaan tidak bisa dipertentangkan lagi, dengan demikian kehadiran Islam di muka bumi khususnya di Indonesia, diharapkan mampu dipahami dengan baik sesuai dengan perintah Allah SWT dan ajaran Nabi Muhammad SAW.

Riset ini tentu masih banyak kelemahan dan kekurangan, maka saran bagi para peneliti selanjutnya untuk memperbaiki lebih detail di setiap kekurangan yang ada, sehingga kekurangan itu dapat diperbaiki ke depannya. 


\section{Daftar Pustaka}

Madjid, Madjid. 1992. Islam Dotrin dan Peradaban: Sebuah Telaah Kritis Tentang Masalah Keimanan, Kemanusiaan dan Kemoderenan. Jakarta: Paramadina.

Madjid, Madjid. 2010. Islam Agama Kemanusiaan: Membangun Tradisi dan Visi Baru Islam Indonesia. Jakarta: Paramadina.

Madjid, Madjid. 1997. Masyarakat Religius, Membumimikan Nilai-Nilai Islam Dalam Kehidupan Masyarakat. Jakarta: Paramadina.

Madjid, Madjid. Tanpa tahun. Nilai-Nilai Agama Islam: Pandangan Dasar Paramadina. Jakarta, Paramadina.

Madjid, Nurcholish, 1998. Dialog Keterbukaan Artikulasi Nilai Islam Dalam Wacana Sosial Politik Kontemporer, Jakarta: Paramdina.

Munawar Rahman, Budhy. 2019. Karya Lengkap Nurcholish Madjid, Keislaman, Keindonesiaan dan Kemodernan. Jakarta: NCMS.

Nafis Wahyuni, Muhammad, 2014. Cak Nur Sang Guru Bangsa, Biografi Pemikiran Prof. Dr. Nurcholish Madjid, Jakarta: 2014.

Gaus AF, Ahmad. 2010. Api Islam Nurcholish Madjid. Jakarta: Kompas. Arifin, Syamsul Arifin, 2010. Studi Agama, Perspektif Sosiologis dan Isu-Isu Kontemporer, Malang, UMM Press.

Arifin, Syasmsul, 2009. Konstruksi Wacana Pluralisme Agama di Indonesia, Jurnal Humanity, Vol V, No 1.

In'am Esha, Muhammad. 2004. Teologi Pluralisme Dalam Pendidikan Islam, Mencermati Implikasi Pemikiran Nurcholish Madjid. Jurnal Ulul Albab; Vol. 5 No. 2.

Susanto, Edi. 2011. Pemikiran Nurcholish Madjid Tentang Pendidikan Multikultural-Pluralistik, Perspektif Sosiologi Pengetahuan. Desertasi, IAIN Sunan Ampel Surabaya.

Rois, Ahmad. 2013. “Pendidikan Islam Multikultural: Telaah Pemikiran Muhammad Amin Abdullah," Episteme, Jurnal Pengembangan Ilmu Keislaman, Vol.8 No. 2, 2013.

Ma'arif, Syamsul. 2008. The Beuty Of Islam dalam Cinta dan Pendidikan Pluralisme. Semarang: Need's Press.

Muthohirin, Nafik. "Politik Identitas Islam dan Urgensi Pendidikan Multikultural." J-PAI : Jurnal Pendidikan Agama Islam UIN Maulana Malik Ibrahim. Vol. 6. No. 1. JuliDesember (2020)

Arif, Mahmud. 2012. Pendidikan Agama Inklusif-Multikultural, Jurnal Pendidikan Islam, Vol. I, No. 1. 
Afandi, Agus, 2011. Gerakan Sosial Intelektual Muslim Organik dalam Transformasi Sosial, Religio: Jurnal Studi Agama-Agama,Vol.1,No,2.

Mahmudin, Afif Syaiful, 2018. Pendidikan Islam dan Kesadaran Pluralisme, Jurnal Ta'limuna, Vol. 7, No. 1.

Sumbulah, Umi dan Nurjanah, 2013. Pluralisme Agama, Makna dan Lokalitas Pola Kerukunan Antarumat Beragama, Malang: UIN- Maliki Press.

Khozin, 2006. Jejak-jejak Pendidikan Islam Di Indonesia, Rekonstruksi Sejarah Untuk Aksi, Malang: UMM Press.

Arifin, Syamsul, 2015. Studi Islam Kontemporer, Arus Radikalisasi dan Multikulturalisme Di Indonesia, Malang: Intrans Publishing.

Ma'arif, Ahmad Syafi'i, 2006. Islam Dan Pancasila Sebagai Dasar Negara, Studi Tentang Perdebatan Dalam Konstituate, Jakarta: LP3ES.

Nata, Abuddin, 2012. Pemikiran Pendidikan Islam dan Barat, Jakarta: Rajawali Press. 